\title{
Comparative studies on the durability and moisture performance of wood modified with cyclic $\mathrm{N}$-methylol and N-methyl compounds
}

\section{Lukas Emmerich $^{1}$ (D) Alexander Ehrmann ${ }^{1} \cdot$ Christian Brischke $^{1} \cdot$ Holger Militz $^{1}$}

Received: 26 February 2021 / Accepted: 15 May 2021 / Published online: 8 June 2021

(c) The Author(s) 2021

\begin{abstract}
Glyoxal-based condensation resins like 1,3-dimethylol-4,5-dihydroxyethyleneurea (DMDHEU) have been used to modify wood and improve its resistance against decaying fungi. High biological durability of DMDHEU-treated wood has already been confirmed in laboratory and field tests in the past. However, the modes of protective action behind an improved decay resistance are not fully understood yet. Furthermore, it is questionable how the use of formaldehyde-poor N-methylol and formaldehyde-free $\mathrm{N}$-methyl compounds instead of DMDHEU affects the moisture behavior and durability, respectively. In this study, wood blocks were treated with N-methylol (DMDHEU, methylated DMDHEU) and N-methyl compounds (1,3-dimethyl-4,5-dihydroxyethyleneurea; DMeDHEU). Untreated and modified specimens were exposed to different moisture regimes and wood-destroying fungi in order to study the indicators that control changes in the wetting ability and decay resistance. Both $\mathrm{N}$-methylol and $\mathrm{N}$-methyl compounds decreased the water uptake and release and increased the durability of Scots pine sapwood from 'not durable' (DC 5) to 'very durable to durable' (DC 1-2). However, high fluctuations were observed in water uptake and release as well as mass loss $(M L)$ caused by fungal decay, when modified specimens were tested without passing through a cold-water leaching. Consequently, a significant effect of the leaching procedure according to EN 84 on the durability classification could be established. The latter appeared more pronounced for treatments with $\mathrm{N}$-methyl compounds compared to $\mathrm{N}$-methylol compounds. Finally, wetting ability $\left(k_{\text {wa }}\right)$ and resistance indicating factors $\left(k_{\text {inh }}\right)$ enabled a forecast of high biological durability for both treatments with $\mathrm{N}$-methylol and $\mathrm{N}$-methyl compounds under real service life conditions.
\end{abstract}

Lukas Emmerich

lukas.emmerich@uni-goettingen.de

1 Wood Biology and Wood Products, University of Goettingen, Buesgenweg 4, 37077 Göttingen, Germany 


\section{Introduction}

Non-biocidal, reactive chemicals have been used to modify wooden cell walls (Hill 2011; Gérardin 2016; Sandberg et al. 2017; Jones and Sandberg 2020) and improve its resistance against wood-destroying organisms (Brelid and Westin 2007; Rowell 2012, 2014; Meyer et al. 2012; Alfredsen et al. 2013; Emmerich et al. 2020a). In this field of 'chemical wood modification', glyoxal-based condensation resins such as 1,3-dimethylol-4,5-dihydroxyethyleneurea (DMDHEU, Fig. 1) were also used to modify wood and improve its dimensional stability and decay resistance (Militz 1993; Krause 2006; Bollmus 2011). The latter has been demonstrated during laboratory (Ritschkoff et al. 1999; Krause 2006; Schaffert 2006; Verma et al. 2009; Bollmus 2011) and field decay tests (Emmerich et al. 2020a). The modes of protective action of DMDHEU treatments, which render an improved decay resistance, are not fully understood, yet. However, the decay resistance of modified wood is expected to be influenced by a number of determinants, such as the fixation and location of the chemical within the hierarchical structure of wood and its effect on moisture uptake and moisture distribution within the impregnated xylem. In particular, the fixation and location of the glyoxal resins appear to be influenced by the amount of formaldehyde and the type of catalyst (Krause 2006). To which extent the formaldehyde content of the resin and the added catalyst affect the decay resistance and moisture performance has not yet been clarified and has to be demonstrated.

Besides its original application in textile finishing (Tomasino 1992; Schindler and Hauser 2004; Naderpour et al. 2009), DMDHEU and its derivates have been used for impregnation modification of wood (Emmerich et al. 2019). DMDHEU monomers are manufactured during the synthesis of urea, glyoxal and formaldehyde, with two hydroxymethyl groups $\left(-\mathrm{CH}_{2}-\mathrm{OH}\right)$ being the reactive functional groups of this water-soluble molecule. In padded fabrics, the reaction of the hydroxymethyl groups with hydroxyl $(\mathrm{OH})$ groups of adjacent DMDHEU monomers (selfcondensation) or $\mathrm{OH}$ groups of cellulose via ether bonds (co-condensation) were reported as reaction mechanisms during curing at elevated temperatures (Dhiman and Chakraborty 2017). Ether-modified DMDHEU (mDMDHEU, Fig. 1) monomers can be created by reaction with methanol $\left(\mathrm{CH}_{3}\right)$ or diethylene glycol $\left(\mathrm{C}_{4} \mathrm{H}_{10} \mathrm{O}_{3}\right)$ and were presented to reduce formaldehyde release (Holme 1993). Compared to DMDHEU, mDMDHEU molecules exhibit lower monomer reactivity (Andrews and Trask-Morrell 1997). Beyond that, zero-formaldehyde N-methyl compounds
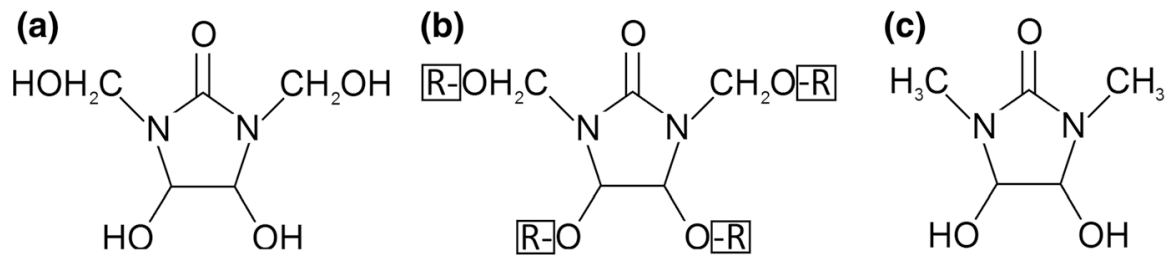

Fig. 1 Structural formula of DMDHEU (a), methylated DMDHEU with $\mathrm{R}=\mathrm{H}$ or $\mathrm{R}=\mathrm{CH}_{3}$ (b) and DMeDHEU (c, Schindler and Hauser 2004, adapted) 
(N,N'-dimethyl-4,5-dihydroxyethyleneurea (DMeDHEU, Fig. 1) can be synthesized from glyoxal and $\mathrm{N}, \mathrm{N}^{\prime}$-dimethylurea. In comparison with the $\mathrm{N}$-methylol compounds (DMDHEU, mDMDHEU), formaldehyde emissions can be eliminated by the use of DMeDHEU. However, a lower fixation of the DMeDHEU molecules is expected, resulting from steric hindrance and lower reactivity of the ring hydroxyl groups $(-\mathrm{OH})$ in the 4,5 position, compared to the hydroxymethyl groups $\left(-\mathrm{CH}_{2}-\mathrm{OH}\right)$ of the N-methylol compounds, which makes the reaction with the $\mathrm{OH}$ groups of cellulose less likely (Jung et al. 1969; Frick 1985, 1986; Bajaj 2002). Nevertheless, an appropriate catalyst may boost the reactivity, thus fixation of zero-formaldehyde DMeDHEU (Paul 2014).

During a vacuum-pressure impregnation with an aqueous solution of DMDHEU and its derivates, the resin molecules enter the water-swollen wood cell wall (Krause et al. 2003; Emmerich and Militz 2020). A subsequent curing at elevated temperatures $\left(>100{ }^{\circ} \mathrm{C}\right)$ removes the solvent (water) and fixates the resin inside the wooden matrix (Schaffert 2006). The reaction mechanisms, which lead to an irreversible fixation in wood, were suggested to be similar to cellulose-based fabrics (Krause et al. 2003; Emmerich et al. 2020b). Wood specimens experience an increase in dry mass ('weight percent gain,' WPG) and dry dimension, which is commonly denoted as 'cell wall bulking' $(C W B)$ and an indicator for deposition of resin molecules inside the cell wall, filling the space between cell wall matrix polymers (Krause 2006; Emmerich and Militz 2020). At high chemical loading (WPG), resins may also be deposited in the cell lumen (Krause et al. 2003; Emmerich et al. 2020b).

DMDHEU and mDMDHEU treatments of wood can significantly improve the resistance against wood-destroying fungi (Militz 1993; Krause 2006; Schaffert 2006; Verma et al. 2009; Bollmus 2011). A variety of decay tests with small clear and homogeneously treated specimens confirmed that $\mathrm{N}$-methylol compounds have potential to improve the durability of non-durable wood species (durability class $5, \mathrm{DC} 5)$ to a level which corresponds to DC 1-2, i.e., 'very durable' to 'durable' (EN 350, 2016). Furthermore, field tests with larger DMDHEU-treated wood specimens revealed a significantly improved decay resistance under different exposure conditions (Emmerich et al. 2020a). However, the effect of a DMDHEU treatment varied between different wood species. While DMDHEU-treated Scots pine sapwood appeared sound after nine years of exposure, an interior rot (decay rating 4, EN 252, 2015) was detected in DMDHEU-treated beech specimens, while outer regions of the specimens appeared sound. This was attributed to an inhomogeneous penetration and uneven distribution of reacted DMDHEU after curing, rather than minor potential of the DMDHEU treatment to improve the decay resistance of wood. Emmerich et al. (2021) showed that hyphae of wood-destroying fungi were able to grow through a protected zone (i.e., through modified wood) and keep their ability to degrade adjacent untreated wood.

Recent studies discussed different modes of protective action against wooddestroying fungi in chemically modified wood, as they are expected to be neither of toxic nature for the fungus nor to affect the decay mechanisms of the fungus irreversibly. Rowell et al. (2009) suggested that the reduced cell wall moisture content $(M C)$ in modified wood is inhibiting fungal decay. Further analysis of the brown rot decay resistance in DMDHEU-treated wood indicated that moisture exclusion 
caused by reductions in the wood cell wall void volume is a key parameter, which delays the start of wood decay (Ringman et al. 2014). Hence, micropore blocking and a reduced number of accessible $\mathrm{OH}$ groups may affect the degradation rate of decay fungi, after decay is initiated (Hill 2009; Ringman et al. 2014). Alfredsen et al. (2015) analyzed $M C$ levels in modified wood during decay testing. Although $M C$ was high enough to allow fungal infestation, no mass loss $(M L)$, respectively decay, occurred. Hence, it was concluded that the moisture distribution in the wood cell wall and the accessibility of water around fungal hyphae were the decisive parameter affecting fungal decay. Fungal decay might decrease with increase in chemical deposits inside the cell walls. For DMDHEU and its derivatives, higher cell wall deposits had been reported with decreasing formaldehyde content of the resin molecules (DMeDHEU > mDMDHEU > DMDHEU; Krause et al. 2003). However, zeroformaldehyde DMeDHEU had not yet been tested to improve the decay resistance of wood, as the fixation was found to be significantly lower compared to the N-methylol compounds DMDHEU and mDMDHEU.

The present study aimed to investigate how cell wall modification with DMDHEU and its derivatives affects the wetting ability and decay resistance of wood. In particular, the impact of (1) the formaldehyde content and (2) the type and amount of catalyst on the biological durability of wood was analyzed after treatment with glyoxal-based resins. Durability test data were collected from tests with treated specimens before and after a cold-water leaching, to quantify the effect of mass changes by non-fixated chemicals on the durability assessment. Laboratory indicators were used to predict the performance of the tested materials outdoors on the basis of a dose-response resistance model according to Meyer-Veltrup et al. (2017).

\section{Materials and methods}

\section{Wood material and treatment process}

Scots pine sapwood (Pinus sylvestris L.) with an average density of $0.46( \pm 0.03) \mathrm{g} \mathrm{cm}^{-3}$ was used for the experiments. Prior to the treatments, specimens of $25 \times 15 \times 50 \mathrm{~mm}^{3}$ and $10 \times 5 \times 100 \mathrm{~mm}^{3}$ (radial $\times$ tangential $\times$ longitudinal) were oven-dried at $103 \pm 2{ }^{\circ} \mathrm{C}$ for $48 \mathrm{~h}$. The initial dry mass and dimensions were measured before oven-dry specimens were treated with aqueous solutions of 1,3-dimethylol-4,5-dihydroxyethyleneurea (DMDHEU), methylated DMDHEU (mDMDHEU) and 1,3-dimethyl-4,5-dihydroxyethyleneurea (DMeDHEU, Fig. 1). Treatments were performed in order to analyze the effect of (1) the modifying agent and its ring hydroxymethyl $\left(-\mathrm{CH}_{2}-\mathrm{OH}\right)$ and hydroxyl $(-\mathrm{OH})$ groups' reactivity and (2) of the catalyst added to the modifying agent on the moisture behavior and biological durability of wood.

For testing the impact of the different formaldehyde containing agents, DMDHEU, mDMDHEU (ultra-low formaldehyde) and DMeDHEU (formaldehydefree) solutions were diluted with water to solid contents of $20 \%$.

Based on experiences from previous studies (e.g. Krause et al. 2003; Krause 2006), metal salt catalysts were considered for the treatments solely. This was done to avoid 
an undesired decrease in the $\mathrm{pH}$ of the treatment solutions, as observed with acidic catalysts, which resulted in a remarkable degradation and depolymerization of the cell wall polymers when impregnated wood blocks were exposed to elevated temperature during the fixation phase (Xie et al. 2005). Magnesium chloride $\left(\mathrm{MgCl}_{2}\right)$ has been recommended and intensively analyzed as catalyst for the DMDHEU treatment process (Krause 2006). However, chlorides may trigger dioxin production during the combustion process of modified wood at the end of life cycle. Thus, this study investigated magnesium and copper nitrate as alternative catalysts. Magnesium nitrate $\left(\mathrm{Mg}\left(\mathrm{NO}_{3}\right)_{2}\right)$, magnesium chloride $\left(\mathrm{MgCl}_{2}\right)$ and copper nitrate $\left(\mathrm{Cu}\left(\mathrm{NO}_{3}\right)_{2}\right)$ were added to the treatment solution, in a concentration of $1 \%$ related to the added stock solution of the $\mathrm{N}$-methylol and N-methyl compounds. The effect of the catalyst concentration was tested with DMDHEU, which was further mixed with all three catalysts at 2 and 5\% related to the added stock solution (Table 1).

Oven-dry specimens were impregnated with the treatment solutions (Table 1) by applying a vacuum $(5 \mathrm{kPa})$ for $1 \mathrm{~h}$, followed by an over-pressure phase at $1200 \mathrm{kPa}$ for $2 \mathrm{~h}$. Fully impregnated specimens were removed from the treatment solution and stored at room climate for $168 \mathrm{~h}$, followed by a subsequent curing at $120{ }^{\circ} \mathrm{C}$ for $48 \mathrm{~h}$. The dry mass and dimensions of the treated specimens were recorded after heat curing. Weight percent gain (WPG [\%]) and cell wall bulking $(C W B[\%])$ were calculated according to Eqs. 1 and 2.

$$
W P G=\frac{\left(m_{\text {final }}-m_{\text {initial }}\right)}{m_{\text {initial }}} 100
$$

$W P G$ weight percent gain after impregnation and heat curing at $120{ }^{\circ} \mathrm{C}[\%] ; m_{\text {initial }}$ initial dry mass of untreated wood; $m_{\text {final }}$ dry mass after treatment $[\mathrm{g}]$.

$$
C W B=\frac{\left(A_{\text {final }}-A_{\text {initial }}\right)}{A_{\text {initial }}} 100
$$

$C W B$ cell wall bulking after impregnation and curing at $120{ }^{\circ} \mathrm{C}[\%] ; A_{\text {initial }}$ initial dry cross-sectional area (radial $\times$ tangential) of untreated wood $\left[\mathrm{mm}^{2}\right] ; A_{\text {final }}$ dry crosssectional area (radial $\times$ tangential) after treatment $\left[\mathrm{mm}^{2}\right]$.

Half of the specimens per treatment collective $\left(n=24 \quad\left(25 \times 15 \times 50 \mathrm{~mm}^{3}\right.\right.$, radial $\times$ tangential $\times$ longitudinal $) ; n=10\left(10 \times 5 \times 100 \mathrm{~mm}^{3}\right.$, radial $\times$ tangential $\times$ longitudinal)) underwent a cold-water leaching with deionized water according to EN 84 (2020). Leached specimens were dried at ambient conditions for $168 \mathrm{~h}$ followed by drying at $103{ }^{\circ} \mathrm{C}$ until constant mass (moisture content $(M C)=0 \%$ ). The dry mass and dimensions after leaching were measured, and $W P G$ and $C W B$ after leaching were calculated according to Eqs. 1 and 2. 
Table 1 Weight percent gain $(W P G)$ and cell wall bulking $(C W B)$ of the modified specimens $\left(25 \times 15 \times 50 \mathrm{~mm}^{3}\right.$, radial $\times$ tangential $\times$ longitudinal $)$ after heat curing and cold-water leaching according to EN 84 (2020)

\begin{tabular}{|c|c|c|c|c|c|}
\hline \multicolumn{2}{|l|}{ Catalyst } & \multicolumn{2}{|l|}{$W P G(\%)$} & \multicolumn{2}{|l|}{$C W B(\%)$} \\
\hline Type & Conc. $(\%)$ & After curing & After leaching & After curing & After leaching \\
\hline \multicolumn{6}{|c|}{ Untreated reference } \\
\hline- & - & - & $-0.9( \pm 0.2)$ & - & $0.3( \pm 0.2)$ \\
\hline \multicolumn{6}{|l|}{$D M D H E U$} \\
\hline \multirow[t]{3}{*}{$\mathrm{Mg}\left(\mathrm{NO}_{3}\right)_{2}$} & 1.0 & $33.6( \pm 2.0)^{\mathrm{b}}$ & $32.4( \pm 3.4)$ & $5.4( \pm 0.5)^{b}$ & $5.3( \pm 0.6)$ \\
\hline & 2.0 & $37.9( \pm 2.1)^{\mathrm{a}, \mathrm{b}}$ & $35.4( \pm 3.7)$ & $5.0( \pm 0.3)^{\mathrm{a}}$ & $5.2( \pm 0.7)$ \\
\hline & 5.0 & $36.7( \pm 2.2)^{\mathrm{b}}$ & $34.2( \pm 2.3)^{\mathrm{a}}$ & $4.7( \pm 0.6)^{b}$ & $4.9( \pm 0.4)$ \\
\hline \multirow[t]{3}{*}{$\mathrm{MgCl}_{2}$} & 1.0 & $34.9( \pm 2.7)^{\mathrm{b}}$ & $33.2( \pm 2.4)$ & $5.4( \pm 0.4)^{b}$ & $5.7( \pm 0.4)^{\mathrm{b}}$ \\
\hline & 2.0 & $31.8( \pm 1.1)^{\mathrm{a}, \mathrm{b}}$ & $32.3( \pm 2.7)$ & $4.5( \pm 0.4)^{\mathrm{a}, \mathrm{b}}$ & $5.1( \pm 0.6)^{\mathrm{b}}$ \\
\hline & 5.0 & $34.8( \pm 1.8)^{\mathrm{b}}$ & $31.6( \pm 2.5)^{\mathrm{a}}$ & $4.7( \pm 0.3)^{b}$ & $4.7( \pm 0.4)^{\mathrm{b}}$ \\
\hline \multirow[t]{3}{*}{$\mathrm{Cu}\left(\mathrm{NO}_{3}\right)_{2}$} & 1.0 & $35.1( \pm 2.9)$ & $33.7( \pm 2.0)$ & $5.0( \pm 0.3)$ & $5.5( \pm 0.3)^{\mathrm{b}}$ \\
\hline & 2.0 & $35.9( \pm 2.7)^{\mathrm{a}}$ & $34.0( \pm 2.3)$ & $4.8( \pm 0.6)$ & $4.9( \pm 0.3)^{\mathrm{b}}$ \\
\hline & 5.0 & $34.9( \pm 2.8)$ & $34.9( \pm 1.8)^{\mathrm{a}}$ & $5.0( \pm 0.6)$ & $5.0( \pm 0.8)$ \\
\hline \multicolumn{6}{|c|}{$m D M D H E U$} \\
\hline $\mathrm{Mg}\left(\mathrm{NO}_{3}\right)_{2}$ & 1.0 & $34.2( \pm 2.1)$ & $32.1( \pm 3.0)$ & $6.6( \pm 0.8)^{\mathrm{c}}$ & $5.6( \pm 0.5)$ \\
\hline $\mathrm{MgCl}_{2}$ & & $34.0( \pm 1.6)$ & $30.8( \pm 1.0)^{\mathrm{c}}$ & $6.4( \pm 0.4)^{\mathrm{c}}$ & $6.0( \pm 0.4)$ \\
\hline $\mathrm{Cu}\left(\mathrm{NO}_{3}\right)_{2}$ & & $37.0( \pm 4.1)$ & $31.8( \pm 2.7)$ & $6.2( \pm 0.4)^{\mathrm{c}}$ & $5.6( \pm 0.7)$ \\
\hline \multicolumn{6}{|c|}{$\mathrm{DMeDHEU}$} \\
\hline $\mathrm{Mg}\left(\mathrm{NO}_{3}\right)_{2}$ & 1.0 & $33.6( \pm 2.8)^{\mathrm{a}}$ & $15.2( \pm 1.3)^{\mathrm{a}, \mathrm{c}}$ & $9.7( \pm 0.6)^{\mathrm{a}, \mathrm{c}}$ & $5.8( \pm 0.5)^{\mathrm{a}}$ \\
\hline $\mathrm{MgCl}_{2}$ & & $26.2( \pm 1.0)^{\mathrm{a}, \mathrm{c}}$ & $11.6( \pm 0.4)^{\mathrm{a}, \mathrm{c}}$ & $9.8( \pm 0.3)^{\mathrm{a}, \mathrm{c}}$ & $5.1( \pm 0.4)^{\mathrm{a}, \mathrm{c}}$ \\
\hline $\mathrm{Cu}\left(\mathrm{NO}_{3}\right)_{2}$ & & $31.7( \pm 2.1)^{\mathrm{a}, \mathrm{c}}$ & $12.7( \pm 1.0)^{\mathrm{a}, \mathrm{c}}$ & $8.9( \pm 0.4)^{\mathrm{a}, \mathrm{c}}$ & $5.0( \pm 0.4)^{\mathrm{a}, \mathrm{c}}$ \\
\hline
\end{tabular}

Average values based on 24 replicates are displayed and standard deviations are shown in parentheses. Letters indicate significant differences (significance level: $p<0.001$ ) with 'a': significant differences between different catalysts at identic concentration level for one specific modification chemical, 'b': significant differences between different catalyst' concentrations for one specific catalyst and modification chemical and 'c': significant differences between mDMDHEU or DMeDHEU treatments to DMDHEU, combined with identic catalyst systems and concentrations

\section{W24-tests (24 $\mathrm{h}$ water uptake and release tests)}

\section{Liquid water uptake by submersion}

Specimens of $10 \times 5 \times 100 \mathrm{~mm}^{3}$ (radial $\times$ tangential $\times$ longitudinal) were ovendried at $103{ }^{\circ} \mathrm{C}$ until constant mass $(M C=0 \%)$. The dry mass was determined to the nearest $10^{-3} \mathrm{~g}$. Oven-dry specimens were submerged in a sealed plastic container with deionized water. The plastic containers were placed in a climate chamber at $20{ }^{\circ} \mathrm{C}, 65 \%$ relative humidity ( $R H$; 'normal climate'). During submersion, specimens were separated from each other by square-shaped stainlesssteel meshes. The specimens were removed after $24 \mathrm{~h}$ of submersion and weighed 
again. The liquid water uptake of the specimens ( $\left.W 24_{\text {submersion }}\right)$ was determined, and the resulting $M C$ was calculated following Eq. 3.

$$
W 24_{\text {submersion }}=\frac{\left(m_{\text {submerged }}-m_{0}\right)}{m_{0}} 100
$$

$W 24_{\text {submersion }}$ liquid water uptake during $24 \mathrm{~h}$ submersion [\%]; $m_{0}$ oven-dry mass before submersion [g]; $m_{\text {submerged }}$ mass after $24 \mathrm{~h}$ of submersion [g].

\section{Water vapor uptake in water-saturated atmosphere}

Specimens of $10 \times 5 \times 100 \mathrm{~mm}^{3}$ (radial $\times$ tangential $\times$ longitudinal) from liquid water uptake testing ( $\left.W 24_{\text {submersion }}\right)$ were again oven-dried at $103{ }^{\circ} \mathrm{C}$ until constant mass. The oven-dry mass was determined to the nearest $10^{-3} \mathrm{~g}$. The bottom of a miniature climate chamber (sealed plastic container with stainless-steel perforated plates) was filled with 51 deionized water. Wood specimens were placed on stainless-steel plates above the water, with a distance of ca. $5 \mathrm{~mm}$ between them. The containers were stored in a climate chamber at $20{ }^{\circ} \mathrm{C}, 65 \% \mathrm{RH}$, and specimens were removed and weighed again after $24 \mathrm{~h}$. The water vapor uptake of the specimens $\left(W 24_{\mathrm{EMC} \sim 100 \% \mathrm{RH}}\right)$ was determined and the resulting $M C$ was calculated according to Eq. 4.

$$
W 24_{\mathrm{EMC} \sim 100 \% \mathrm{RH}}=\frac{\left(m_{E M C \sim 100 \% \mathrm{RH}}-m_{0}\right)}{m_{0}} 100
$$

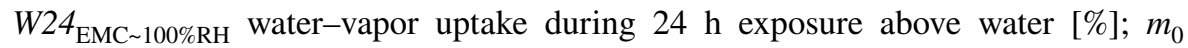
oven-dry mass before exposure [g]; $m_{\mathrm{EMC} ~ 100 \% \mathrm{RH}}$ mass after $24 \mathrm{~h}$ exposure above water $[\mathrm{g}]$.

\section{Desorption}

After the water vapor uptake test, specimens of $10 \times 5 \times 100 \mathrm{~mm}^{3}$ (radial $\times$ tangential $\times$ longitudinal) were stored in sealed containers above water at $20{ }^{\circ} \mathrm{C}$ (approximately $100 \% \mathrm{RH}$ ) until constant mass. The mass at approx. cell wall saturation $(C W S)$ was determined to the nearest $10^{-3} \mathrm{~g}$. Specimens were placed with the $10 \times 100 \mathrm{~mm}^{2}$ surface on freshly activated silica gel in sealed boxes (approx. $0 \%$ $R H$ ) and weighed again after $24 \mathrm{~h}$. The water vapor release (desorption) of the specimens during $24 \mathrm{~h}$ was determined and expressed as a relative value of the mass at CWS according to Eq. 5.

$$
W 24_{\mathrm{MC} \sim 0 \% \mathrm{RH}}=\frac{\left(m_{\mathrm{CWS}}-m_{\mathrm{MC} \sim 0 \% \mathrm{RH}}\right)}{m_{\mathrm{CWS}}} 100
$$

$W 24{ }_{\mathrm{MC} \sim 0 \% \mathrm{RH}}$ water-vapor release during $24 \mathrm{~h}$ exposure at nearly $0 \% \mathrm{RH}[\%] ; m_{\mathrm{CWS}}$ mass at CWS [g]; $m_{\mathrm{MC} \sim 0 \mathrm{RH}}$ mass after $24 \mathrm{~h}$ exposure over silica gel [g]. 


\section{Capillary water uptake tests (CWU)}

Short-term water absorption was measured according to a modified EN 1609 (2013) procedure using a hydraulic lifting unit. Specimens of $10 \times 5 \times 20 \mathrm{~mm}^{3}$ (radial $\times$ tangential $\times$ longitudinal) were conditioned at $20{ }^{\circ} \mathrm{C}, 65 \% R H$ until constant mass was achieved. The axial specimen surfaces were positioned to be in contact with water and fixed. After $200 \mathrm{~s}$, specimens and liquid surface water were removed and the specimens weighed to the nearest $10^{-3} \mathrm{~g}$. The capillary water uptake was determined over time in $\mathrm{g} / \mathrm{cm}^{2}$ according to Eq. 6 .

$$
C W U=\frac{m_{200 \mathrm{~s}}-m_{65 \% \mathrm{RH}}}{A}
$$

$C W U$ capillary water uptake during $200 \mathrm{~s}\left[\mathrm{~g} / \mathrm{cm}^{2}\right] ; m_{200 \mathrm{~s}}$ mass after $200 \mathrm{~s}$ in contact with water $[\mathrm{g}] ; m_{65 \% \text { RH }}$ mass at $20{ }^{\circ} \mathrm{C} / 65 \% R H$ [g]; $A$ cross section of specimens at $20{ }^{\circ} \mathrm{C} / 65 \% R H\left[\mathrm{~cm}^{2}\right]$.

\section{Durability tests according to EN 113-2 (2021)}

Untreated and modified specimens were subjected to decay tests with basidiomycete monocultures according to EN 113-2 (2021). Prior to incubation, the oven-dry mass of the specimens was determined. Scots pine sapwood and European beech (Fagus sylvatica L.) specimens of $25 \times 15 \times 50 \mathrm{~mm}^{3}$ (radial $\times$ tangential $\times$ longitudinal) served as virulence control. After steam sterilization at $121{ }^{\circ} \mathrm{C}$ for $20 \mathrm{~min}$, two specimens of the same material were placed on fungal mycelium in a culture vessel (polyethylene jars). For each material $n=12$ replicate specimens (6 plastic cups) were incubated corresponding to the WPG levels shown in Table 1 . The specimens were placed on stainlesssteel washers to avoid direct contact to the overgrown malt agar (4\%). The incubation period was 16 weeks. The following test fungi were used:

- Coniophora puteana (Schum.:Fr.) P. Karsten BAM Ebw.

- Trametes versicolor (L.:Fr.) Pilat CTB 863A

After incubation, specimens were cleaned from adhering mycelium. Specimens were weighed to the nearest $10^{-3} \mathrm{~g}$ immediately after harvest and after oven drying at $103 \pm 2.0^{\circ} \mathrm{C}$ until constant mass $(M C=0 \%)$. Mass loss $(M L)$ and $M C$ of the materials were determined according to Eqs. 7 and 8.

$$
\begin{aligned}
& M L=\frac{\left(m_{0}-m_{i, 0}\right)}{m_{0}} 100 \\
& M C=\frac{\left(m_{i}-m_{0}\right)}{m_{0}} 100
\end{aligned}
$$

$M L$ mass loss after decay testing [\%]; $M C$ moisture content after 16 weeks incubation [\%]; $m_{0}$ initial oven-dry mass before incubation $[\mathrm{g}] ; m_{i}$ mass after incubation $[\mathrm{g}] ; m_{i, 0}$ oven-dry mass after incubation $[\mathrm{g}]$. 


\section{Durability assessment}

The durability of modified specimens against white rot and brown rot fungi was calculated as the quotient (x-value, CEN/TS 15083-2, 2005) of the median $M L$ of the modified specimens and the median $M L$ of the untreated Scots pine sapwood specimens (Eq. 9).

$$
x=\frac{M L_{\text {med, mod. specimens }}}{M L_{\text {med, reference }}}
$$

$M L_{\text {med, mod. specimens }}$ median mass loss of modified specimens after decay testing [\%]; $M L_{\text {med, reference }}$ median mass loss of untreated Scots pine sapwood specimens after decay testing [\%].

Durability classes were assigned either on the basis of median and mean $M L(\%)$ or on the basis of the corresponding $x$-values according to the scheme shown in Table 2.

\section{Predicting the field performance based on a factor approach}

To predict the field performance of the tested materials, a model approach has been applied according to Meyer-Veltrup et al. (2017) and Isaksson et al. (2014). The model describes the climatic exposure on the one hand and the resistance of the material on the other hand. Thereby, a selected design solution and choice of material is accepted if Eq. 10 is satisfied.

$$
\text { Exposure } \leqslant \text { Resistance }
$$

For wooden constructions, this condition is expressed as a dose, which is expressed in days [d] with optimum moisture and temperature conditions for fungal decay (Eq. 11, Isaksson et al. 2013).

Table 2 Durability classes (DC, EN 350, 2016) based on median or mean $M L$ according to EN 113-2 (2021) and based on relative median $M L$ ( $x$-values) according to CEN/TS 15083-2 (2005)

\begin{tabular}{llll}
\hline $\begin{array}{l}\text { Durability class } \\
(\mathrm{DC})\end{array}$ & Description & $\begin{array}{l}\text { EN 113-2 (2021) } \\
\text { Median/Mean } M L(\%)\end{array}$ & $\begin{array}{l}\text { CEN/TS 15083-2 (2005) } \\
x \text {-value }\end{array}$ \\
\hline 1 & & $\leq 5$ & $\leq 0.10$ \\
2 & Very durable & $>5$ to $\leq 10$ & $0.10<\times \leq 0.20$ \\
3 & Durable & $>10$ to $\leq 15$ & $0.20<\times \leq 0.45$ \\
4 & Moderately durable & $>15$ to $\leq 30$ & $0.45<\times \leq 0.80$ \\
5 & Slightly durable & $>30$ & $>0.80$ \\
\hline
\end{tabular}




$$
D_{\mathrm{Ed}} \leqslant D_{\mathrm{Rd}}
$$

$D_{\mathrm{Ed}}$ exposure dose determined by daily averages of temperature and $M C[\mathrm{~d}] ; D_{\mathrm{Rd}}$ resistance dose as a material property [d].

The exposure dose $\left(D_{\mathrm{Ed}}\right)$ depends on an annual dose at a specific geographical site $\left(D_{\mathrm{E} 0}\right)$ and various factors considering the effect of local climate conditions, driving rain, sheltering, distance from ground and design details. Isaksson et al. (2014) provided a detailed description of the corresponding exposure model.

In this study, the resistance dose $\left(D_{\mathrm{Rd}}\right)$ was considered as the counter part of the $D_{\mathrm{Ed}}$. The $D_{\mathrm{Rd}}$ was considered to be the product of a critical dose $D_{\text {crit }}$ (325 days, Isaksson et al. 2013), which corresponds to decay rating 1 according to EN 252 (2015), and the wetting ability $\left(k_{\text {wa }}\right)$ and inherent durability $\left(k_{\text {inh }}\right)$ of a specific material. According to Isaksson et al. (2014), the resistance dose $\left(D_{\mathrm{Rd}}\right)$ was calculated following Eq. 12.

$$
D_{\mathrm{Rd}}=D_{\text {crit }} \times k_{\text {wa }} \times k_{\text {inh }}
$$

$D_{\mathrm{Rd}}$ resistance dose [d]; $D_{\text {crit }}$ critical dose corresponding to decay rating 1 (slight decay) according to EN 252 (2015) [d]; $k_{\text {wa }}$ factor accounting for the wetting ability of the tested materials, relative to the untreated reference Norway spruce (Picea abies (L.) H. Karst.) [-]; $k_{\text {inh }}$ factor accounting for the inherent protective properties of the tested materials against decay, relative to the untreated reference Norway spruce $[-]$.

On the basis of the results from moisture uptake and release tests, the wetting ability factor $k_{\text {wa }}$ was calculated. The inherent resistance factor $k_{\text {inh }}$ was calculated based on results from durability tests. Both factors were first calculated relative to the untreated reference Scots pine sapwood and afterward converted to $k_{\mathrm{wa}}$ and $k_{\text {inh }}$ relative to Norway spruce via $f_{\text {Norway spruce/Scots pine sw }}$ factors following Table 3. According to Brischke et al. (2021) and to avoid unrealistically high relative values, a threshold was set for both factors in the range: $0<k_{\mathrm{wa}} \leq 18$ and $0<k_{\text {inh }} \leq 18$. Both factors were used to determine the resistance dose $D_{\mathrm{Rd}}$ of the differently modified materials.

Table 3 Conversion factors for $k_{\mathrm{wa}}$ and $k_{\mathrm{inh}}$ from Scots pine (Pinus sylvestris L.) sapwood (sw) to Norway spruce (Picea abies (L.) H. Karst.) according to Alfredsen et al. (2021)

\begin{tabular}{lllll}
\hline Factor & Test procedure & Norway spruce & Scots pine sw & $f_{\text {Norway spruce/Scots pine sw }}$ \\
\hline$k_{\text {wa }}$ & $W 24_{\text {submersion }}(\%)$ & 1.00 & 1.01 & 0.99 \\
& $W 24_{\mathrm{EMC} \sim 100 \% \mathrm{RH}}(\%)$ & 1.00 & 0.87 & 1.15 \\
& $W 24_{\mathrm{MC} \sim 0 \% \mathrm{RH}}(\%)$ & 1.00 & 0.83 & 1.20 \\
& $C W U\left(\mathrm{~g} / \mathrm{cm}^{2}\right)$ & 1.00 & 1.03 & 0.97 \\
$k_{\text {inh }}$ & $M L_{\text {White rot }}(\%)$ & 1.00 & 0.86 & 1.16 \\
& $M L_{\text {Brown rot }}(\%)$ & 1.00 & 0.89 & 1.13 \\
\hline
\end{tabular}




\section{Results and discussion}

\section{Macroscopic changes by the treatments with $\mathrm{N}$-methylol and $\mathrm{N}$-methyl compounds}

Small, clear wood blocks experienced an increase in dry mass and dry dimensions by the treatments with DMDHEU, methylated DMDHEU (mDMDHEU) and DMeDHEU. The increase in dry mass was measured as weight percent gain (WPG, Table 1) and appeared to be independent of the type of catalyst used in combination with the $\mathrm{N}$-methylol compounds DMDHEU and mDMDHEU, apart from $\mathrm{MgCl}_{2}$ which resulted in a lower WPG compared to $\mathrm{Mg}\left(\mathrm{NO}_{3}\right)_{2}$ and $\mathrm{Cu}\left(\mathrm{NO}_{3}\right)_{2}$ at certain concentration levels and when added to an aqueous DMDHEU or DMeDHEU solution. Furthermore, treatments with the N-methylol and N-methyl compounds caused an increase in dry dimensions of the wood blocks, which was measured as cell wall bulking $(C W B$, Table 1) and adduced as an indicator for resin deposits within the cell wall (Rowell and Dickerson 2014). At the same solid content level, the $C W B$ was almost unaffected by the type of catalyst and did not increase with increase in catalyst concentration, which was shown for both treated wood blocks after heat curing and after cold-water leaching. However, the $C W B$ increased in the order of DMDHEU ( $C W B_{\text {mean }}$ 4.9\%), mDMDHEU $\left(C W B_{\text {mean }} 6.4 \%\right)$ and DMeDHEU $\left(C W B_{\text {mean }} 9.5 \%\right.$, Table 1$)$. Thus, the N-methyl compound DMeDHEU appeared to penetrate the wood cell wall more effectively. Here, differences in the molar mass and polarity of $\mathrm{N}$-methylol and $\mathrm{N}$-methyl compounds might be determining for an increased cell wall penetration of the N-methyl compounds, as molar mass and polarity were suggested to be crucial for a cell wall diffusion of chemicals during an impregnation process (Stamm and Seborg 1936).

Slightly reduced WPG $(<14 \%)$ after cold-water leaching (EN 84, 2020) indicated good fixation of the N-methylol compounds. In contrast, the WPG of DMeDHEU-treated specimens decreased by up to $60 \%$ after a leaching procedure, which corresponded to earlier studies from textile finishing (Ziifle et al. 1968; Vanneste 2014) and indicated a low fixation of the $\mathrm{N}$-methyl compound. The lower fixation was attributed to a lower cross-linking density of the $\mathrm{N}$-methyl compounds in wood, which most probably originates from the lower reactivity of the ring hydroxyl groups $(-\mathrm{OH})$ in the 4,5 position, compared to the hydroxymethyl groups $\left(-\mathrm{CH}_{2}-\mathrm{OH}\right)$ in DMDHEU and mDMDHEU molecules (Jung et al. 1969). The decrease in WPG was accompanied by a loss in $C W B$, which was most pronounced in DMeDHEU-treated specimens. After the leaching procedure, DMDHEU $\left(C W B_{\text {mean }} 5.2 \%\right)$, mDMDHEU $\left(C W B_{\text {mean }} 5.7 \%\right)$ and DMeDHEU $\left(C W B_{\text {mean }} 5.3 \%\right)$-treated specimens exhibited similar $C W B$ levels. Negative WPGs were detected in water-leached reference specimens, which were attributed to leaching of water-soluble extractives (Table 1).

\section{Moisture dynamics}

Four different laboratory test procedures were conducted in order to cover different mechanisms representing the moisture dynamics of wood under real service 
conditions. The results for untreated and modified specimens plus corresponding factors describing the wetting ability $\left(k_{\mathrm{wa}}\right)$ are summarized in Table 4. According to Meyer-Veltrup et al. (2017) and Emmerich et al. (2020c), test results measured during exposure to different moisture regimes differed between both treatments and applied test procedures. Scots pine sapwood specimens treated with $\mathrm{N}$-methylol and $\mathrm{N}$-methyl compounds experienced a decrease in water vapor $\left(W 24_{\mathrm{EMC} 100 \% \mathrm{RH}}\right)$ and liquid water uptake $\left(W 24_{\text {submersion }}, C W U\right)$ as well as water vapor release $\left(W 24_{\mathrm{MC} \sim 0 \% \mathrm{RH}}\right)$. This corresponded to earlier studies on the water uptake of DMDHEU-treated solid wood and plywood using various test methods (Krause 2006; Wepner 2006; Xie et al. 2008; Bollmus 2011). Irrespective of the test procedure and type of resin, the data are most scattered for specimens which were heat-cured but not subjected to cold-water leaching (EN 84, 2020). This was attributed to the additional weight of non-fixated chemicals, providing additional sorption sites $(-\mathrm{OH})$ for water inside the matrix of modified specimens (Emmerich et al. 2020b). Clear differences between the effects of N-methylol and N-methyl compounds on the moisture behavior were only evident after subsequent cold-water leaching (EN 84, 2020), which aimed to exclude the effect of non-fixated chemical. On average, the water uptake and release decreased by the modifications in the order of DMeDHEU, mDMDHEU and DMDHEU, but was almost unaffected by the catalyst (Table 4).

\section{Durability against brown and white rot causing basidiomycetes}

Treatments with N-methylol and N-methyl compounds decreased fungal decay by white rot (T. versicolor) and brown rot fungi (C. puteana) significantly. While biodegradation caused significant changes in the morphology of untreated control specimens (i.e. die-breaks (brown rot)), the modified wood blocks retained their shape after incubation with fungal monocultures. This coincided with previous studies with DMDHEU-treated wood (Verma et al. 2009; Bollmus et al. 2019) and mDMDHEUtreated wood (Krause 2006). Mean $M L$ of virulence control specimens after incubation with $T$. versicolor and C. puteana was $30.0 \%$ and $44.0 \%$ in untreated Scots pine sapwood and $30.1 \%$ and $38.9 \%$ in European beech, respectively. Therefore, both fungi were highly virulent and decay tests were valid according to EN 113-2 (2021). Independent of the type of resin, the type and concentration of the catalyst and whether specimens underwent a cold-water leaching or not, $M L$ caused by $T$. versicolor and $C$. puteana decreased from 26.7 to $43.6 \%$ in untreated specimens to $1.2-15.5 \%$ and $0.7-14.5 \%$ in modified specimens, respectively (Fig. 2). However, absolute $M L$ values were higher and varied more, when modified specimens were tested without performing a leaching (EN 84, 2020) prior to the decay tests. This effect was more prominent in specimens treated with the N-methyl compound DMeDHEU, in comparison with the N-methylol compounds, and was attributed to $M L$ by non-fixated chemicals. The latter was included in the measured $M L$ as an add on to the $M L$ caused by fungi. When modified specimens underwent 
Table 4 Moisture content of untreated and modified specimens $\left(10 \times 5 \times 100\right.$ (longitudinal) $\left.\mathrm{mm}^{3}\right)$ after exposure to different moistening regimes, water release during drying and capillary water uptake $(C W U)$ plus the resulting factors accounting for the wetting ability $\left(k_{\mathrm{wa}}\right)$ of the tested materials. $(W 24=24 \mathrm{~h}$ water uptake and release tests)

\begin{tabular}{|c|c|c|c|c|c|c|c|c|c|}
\hline \multicolumn{2}{|l|}{ Catalyst } & \multicolumn{2}{|c|}{$W 24_{\text {submersion }}$} & \multicolumn{2}{|c|}{$W 24_{\mathrm{EMC} \sim 100 \% \mathrm{RH}}$} & \multicolumn{2}{|c|}{$W 24_{\mathrm{MC} \sim 0 \% \mathrm{RH}}$} & \multicolumn{2}{|l|}{$C W U$} \\
\hline Type & Conc. $(\%)$ & Mean $(\%)$ & $k_{\mathrm{wa}}(-)$ & Mean $(\%)$ & $k_{\mathrm{wa}}(-)$ & Mean $(\%)$ & $k_{\mathrm{wa}}(-)$ & Mean & $k_{\mathrm{wa}}(-)$ \\
\hline \multicolumn{10}{|c|}{ Before leaching EN 84 (2020) } \\
\hline \multicolumn{10}{|c|}{ Untreated reference } \\
\hline- & - & 82.9 & 0.99 & 14.8 & 1.15 & 29.3 & 1.20 & 0.19 & 0.97 \\
\hline \multicolumn{10}{|l|}{$D M D H E U$} \\
\hline \multirow[t]{3}{*}{$\mathrm{Mg}\left(\mathrm{NO}_{3}\right)_{2}$} & 1.0 & 52.8 & 1.55 & 20.0 & 1.71 & 16.7 & 1.10 & 0.16 & 1.10 \\
\hline & 2.0 & 49.9 & 1.64 & 9.4 & 1.82 & 29.9 & 1.98 & 0.13 & 1.41 \\
\hline & 5.0 & 50.6 & 1.62 & 9.6 & 1.78 & 19.5 & 1.29 & 0.18 & 0.99 \\
\hline \multirow[t]{3}{*}{$\mathrm{MgCl}_{2}$} & 1.0 & 52.5 & 1.56 & 11.4 & 1.50 & 10.7 & 0.71 & 0.14 & 1.26 \\
\hline & 2.0 & 50.9 & 1.61 & 8.8 & 1.93 & 16.9 & 1.11 & 0.17 & 1.06 \\
\hline & 5.0 & 52.7 & 1.55 & 11.9 & 1.43 & 26.6 & 1.76 & 0.26 & 0.69 \\
\hline \multirow[t]{3}{*}{$\mathrm{Cu}\left(\mathrm{NO}_{3}\right)_{2}$} & 1.0 & 57.0 & 1.44 & 8.5 & 2.00 & 12.7 & 0.84 & 0.06 & 2.87 \\
\hline & 2.0 & 56.6 & 1.45 & 8.2 & 2.08 & 11.9 & 0.79 & 0.05 & 3.40 \\
\hline & 5.0 & 58.3 & 1.40 & 8.6 & 1.98 & 10.7 & 0.71 & 0.04 & 4.31 \\
\hline \multicolumn{10}{|c|}{ mDMDHEU } \\
\hline $\mathrm{Mg}\left(\mathrm{NO}_{3}\right)_{2}$ & 1.0 & 64.0 & 1.28 & 10.7 & 1.59 & 16.0 & 1.06 & 0.20 & 0.90 \\
\hline $\mathrm{MgCl}_{2}$ & & 60.8 & 1.35 & 11.5 & 1.48 & 16.1 & 1.06 & 0.23 & 0.79 \\
\hline $\mathrm{Cu}\left(\mathrm{NO}_{3}\right)_{2}$ & & 60.6 & 1.35 & 9.4 & 1.81 & 20.9 & 1.38 & 0.14 & 1.24 \\
\hline \multicolumn{10}{|l|}{ DMeDHEU } \\
\hline $\mathrm{Mg}\left(\mathrm{NO}_{3}\right)_{2}$ & 1.0 & 60.6 & 1.35 & 13.4 & 1.27 & 17.1 & 1.13 & 0.38 & 0.48 \\
\hline $\mathrm{MgCl}_{2}$ & & 59.2 & 1.38 & 10.1 & 1.68 & 25.0 & 1.65 & 0.36 & 0.49 \\
\hline $\mathrm{Cu}\left(\mathrm{NO}_{3}\right)_{2}$ & & 58.1 & 1.41 & 10.5 & 1.63 & 26.9 & 1.78 & 0.28 & 0.64 \\
\hline \multicolumn{10}{|c|}{ After leaching EN 84 (2020) } \\
\hline \multicolumn{10}{|c|}{ Untreated reference } \\
\hline- & - & 95.4 & 0.99 & 17.2 & 1.15 & 17.6 & 1.20 & 0.16 & 0.97 \\
\hline \multicolumn{10}{|l|}{$D M D H E U$} \\
\hline \multirow[t]{3}{*}{$\mathrm{Mg}\left(\mathrm{NO}_{3}\right)_{2}$} & 1.0 & 56.8 & 1.66 & 14.4 & 1.38 & 13.9 & 0.95 & 0.11 & 1.43 \\
\hline & 2.0 & 55.9 & 1.68 & 11.2 & 1.76 & 13.6 & 0.93 & 0.10 & 1.47 \\
\hline & 5.0 & 54.6 & 1.73 & 10.9 & 1.81 & 12.2 & 0.84 & 0.11 & 1.45 \\
\hline \multirow[t]{3}{*}{$\mathrm{MgCl}_{2}$} & 1.0 & 50.3 & 1.87 & 10.2 & 1.93 & 9.6 & 0.66 & 0.13 & 1.21 \\
\hline & 2.0 & 49.7 & 1.89 & 10.4 & 1.90 & 11.8 & 0.81 & 0.10 & 1.59 \\
\hline & 5.0 & 53.7 & 1.75 & 11.1 & 1.78 & 13.8 & 0.95 & 0.12 & 1.25 \\
\hline \multirow[t]{3}{*}{$\mathrm{Cu}\left(\mathrm{NO}_{3}\right)_{2}$} & 1.0 & 55.9 & 1.68 & 11.3 & 1.75 & 11.5 & 0.78 & 0.01 & 15.04 \\
\hline & 2.0 & 53.3 & 1.77 & 11.2 & 1.77 & 11.1 & 0.76 & 0.02 & 6.19 \\
\hline & 5.0 & 53.4 & 1.77 & 10.9 & 1.82 & 12.8 & 0.88 & 0.01 & 18.00 \\
\hline \multicolumn{10}{|c|}{ mDMDHEU } \\
\hline $\mathrm{Mg}\left(\mathrm{NO}_{3}\right)_{2}$ & 1.0 & 63.1 & 1.49 & 11.8 & 1.68 & 13.8 & 0.94 & 0.12 & 1.24 \\
\hline $\mathrm{MgCl}_{2}$ & & 60.8 & 1.55 & 12.2 & 1.62 & 11.3 & 0.77 & 0.12 & 1.29 \\
\hline $\mathrm{Cu}\left(\mathrm{NO}_{3}\right)_{2}$ & & 62.7 & 1.50 & 13.3 & 1.48 & 16.3 & 1.11 & 0.06 & 2.55 \\
\hline \multicolumn{10}{|c|}{ DMeDHEU } \\
\hline $\mathrm{Mg}\left(\mathrm{NO}_{3}\right)_{2}$ & 1.0 & 83.9 & 1.12 & 15.1 & 1.31 & 17.0 & 1.16 & 0.21 & 0.73 \\
\hline $\mathrm{MgCl}_{2}$ & & 82.8 & 1.14 & 16.6 & 1.19 & 15.0 & 1.03 & 0.19 & 0.80 \\
\hline $\mathrm{Cu}\left(\mathrm{NO}_{3}\right)_{2}$ & & 83.4 & 1.13 & 14.3 & 1.39 & 17.2 & 1.18 & 0.07 & 2.20 \\
\hline
\end{tabular}


a leaching (EN 84, 2020) prior to the decay test, absolute $M L$ values and fluctuations detected over all treatments decreased significantly to $1.2-5.5 \%$ (T. versicolor) and $0.2-4.1 \%$ (C. puteana). Surprisingly, $M L$ detected for DMeDHEU modified and leached specimens was in a similar range compared to treatments with the N-methylol compounds (Fig. 2), although the WPG was less than half of the specimens' $W P G$ treated with DMDHEU and mDMDHEU (Table 1). Furthermore, $C W B$ levels were almost identic in DMDHEU, mDMDHEU and DMeDHEU-treated specimens after cold-water leaching, which indicated that similar amounts of the N-methylol and $\mathrm{N}$-methyl compounds were fixated in the wood cell wall. It was hypothesized that the deposition of the resin molecules, and most probably the co-condensation of the N-methylol and N-methyl compounds with the cell wall polymers, is the dominant factor in reducing the spatial availability for water inside the cell wall (Thybring et al. 2020; Emmerich et al. 2020b), thereby affecting white and brown rot decay (Alfredsen et al. 2015).

\section{Durability classification}

Mass loss data from decay tests were used to classify the biological durability of the differently treated material. Durability classes (DC) according to EN 350 (2016) were assigned on the basis of the mean $M L(\%)$, median $M L(\%)$ and $x$-values calculated according to CEN/TS 15083-2 (2005) (Table 5). Regardless of the calculation basis, modified specimens were classified between 'very durable' (DC 1) and 'slightly durable' (DC 4) without pre-ageing according to EN 84 (2020). Significantly less variations in the DCs appeared, when a cold-water leaching (EN 84, 2020) was performed prior to the decay test. Both, treatments with N-methylol and N-methyl compounds increased the durability from 'not durable' (DC 5, untreated reference) to 'very durable' (DC 1) to 'durable' (DC 2), but DC 1 was predominant (Table 5). As expected, the negative effect of leaching on durability increased with increasing amounts of non-fixated chemicals.

\section{Predicting above ground field performance}

Based on the various wetting ability and decay tests, the factors $k_{\text {wa }}$ and $k_{\text {inh }}$ were calculated for untreated and modified wood with Norway spruce as reference material. Both factors showed variations, which were different for the wetting ability factors $\left(k_{\mathrm{wa}}\right)$ and the resistance indicating factors $\left(k_{\text {inh }}\right)$. Moderate differences between treatments with $\mathrm{N}$-methylol and $\mathrm{N}$-methyl compounds appeared when $k_{\mathrm{wa}}$ and $k_{\text {inh }}$ factors of respectively treated specimens were compared, but differences were even higher, when non-leached and leached modified specimens of the same treatment were compared (Table 6). In the following, only leached specimens were considered for service life prediction.

The material resistance dose $D_{\mathrm{Rd}}$ was calculated according to Eq. 12 and based on the procedure described by Meyer-Veltrup et al. (2017) and Brischke et al. (2021). 


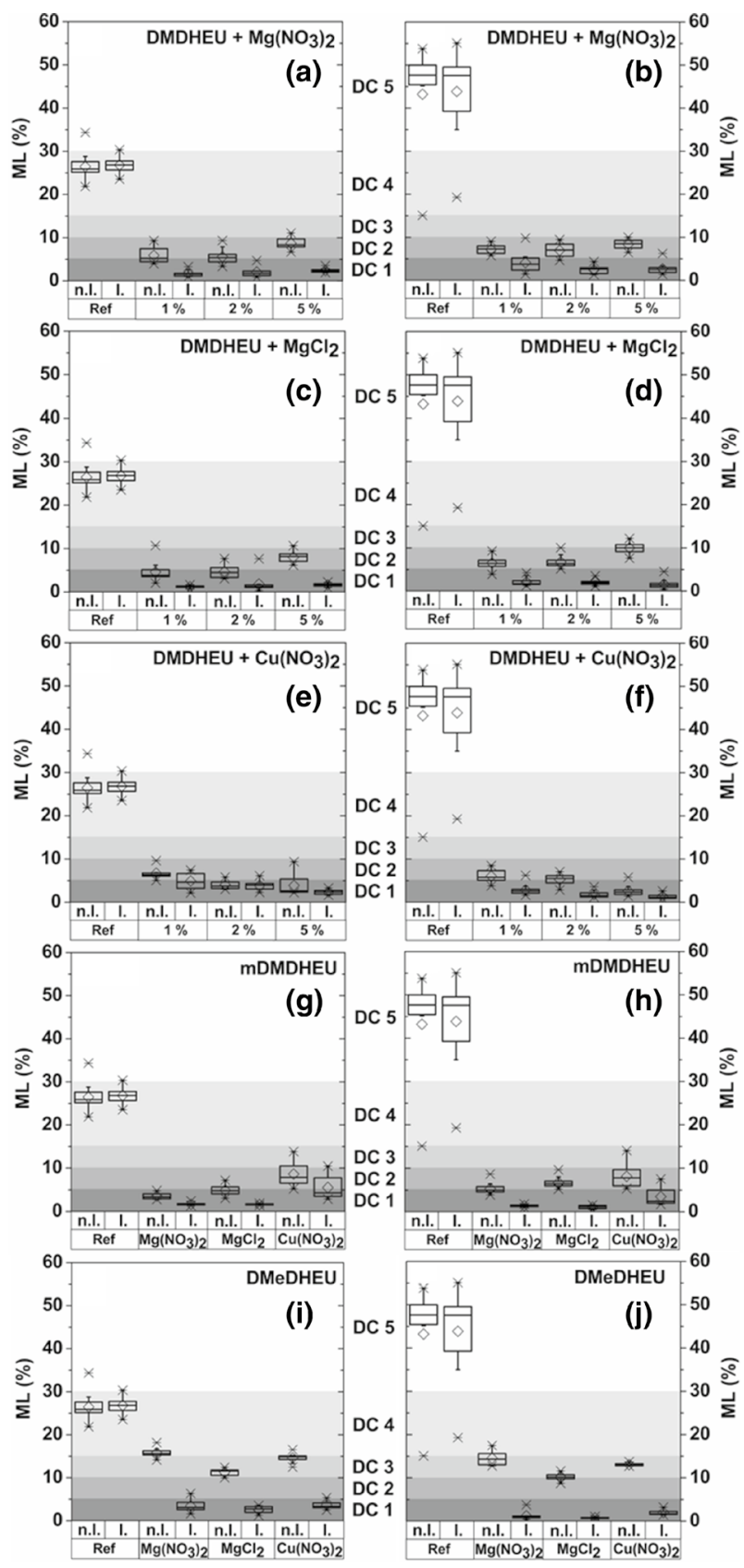

Fig. 2 Mass loss $(M L)$ of untreated (Reference) and modified wood samples after 16 weeks of incubation with Trametes versicolor $(\mathbf{a}, \mathbf{c}, \mathbf{e}, \mathbf{g}, \mathbf{i})$ and Coniophora puteana $(\mathbf{b}, \mathbf{d}, \mathbf{f}, \mathbf{h}, \mathbf{j})$ according to EN 113-2 (2021) and durability class (DC, colored areas) according to EN 113-2 (2021) based on $M L$ values. Specimens were incubated before (n.1.) and after (1.) cold-water leaching according to EN 84 (2020) 


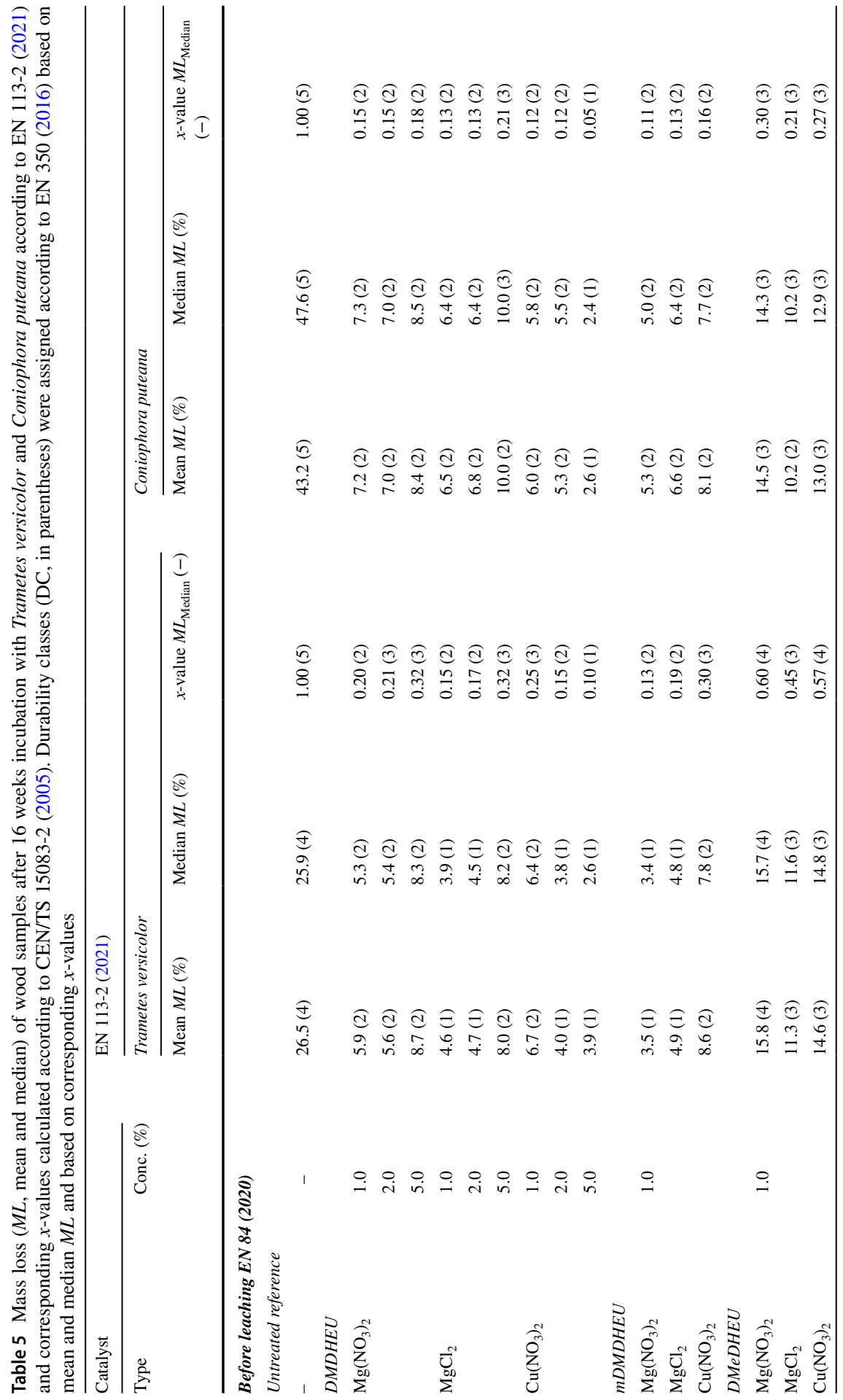




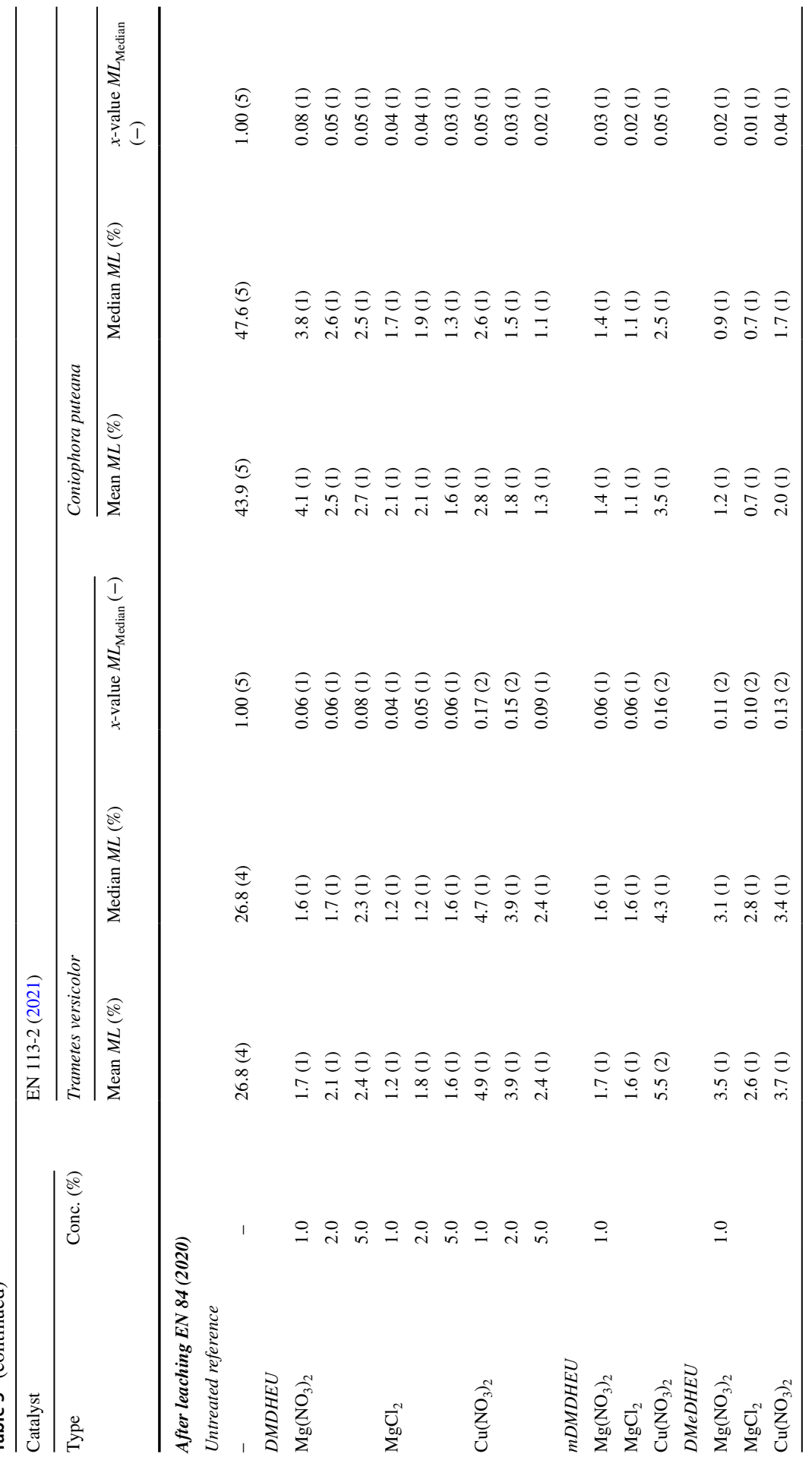


The materials were expected to resist a wood-species independent critical dose $D_{\text {crit }}$ of 325 days of optimum conditions for fungal decay. The highest $D_{\mathrm{Rd}}$ was observed for specimens treated with DMDHEU and $\mathrm{Cu}\left(\mathrm{NO}_{3}\right)_{2}$ as catalyst (Table 6). In contrast to the standardized durability classification system (Table 5, Fig. 2), the applied resistance model allowed to differentiate between durability of different types and concentrations of catalysts that had been used in combination with the N-methylol compound DMDHEU. For instance, the $D_{\mathrm{Rd}}$ in DMDHEU-treated wood was almost threefold, when $\mathrm{Cu}\left(\mathrm{NO}_{3}\right)_{2}$ was used as catalyst instead of $\mathrm{Mg}\left(\mathrm{NO}_{3}\right)_{2}$ or $\mathrm{MgCl}_{2}$.

In the following, the relative resistance dose $D_{\mathrm{Rd}}$, rel. was calculated following Eq. 13, with Norway spruce as reference material.

$$
D_{\mathrm{Rd}, \text { rel. }}=\frac{D_{\mathrm{Rd}, \text { specimen } \mathrm{x}}}{D_{\mathrm{Rd}, \text { reference }}}
$$

$D_{\mathrm{Rd}, \text { rel. }}$ relative resistance dose [-]; $D_{\mathrm{Rd} \text {, specimen x. }}$ resistance dose of tested untreated and modified specimens $[\mathrm{d}] ; D_{\mathrm{Rd}}$, reference resistance dose of the reference material (here: Norway spruce) [d].

Afterward, $D_{\mathrm{Rd}}$, rel. was used to predict the relative decay rate $v_{\mathrm{HDL}}$, rel. (Eq. 14 , Brischke et al. 2021), which is the predicted decay rate of the tested material relative to the predicted decay rate of the reference material. In this specific case, the decay rate expected in a horizontal double-layer design element was considered, which mimics a badly designed terrace decking with high potential for trapping water (e.g., Meyer et al. 2016).

$$
v_{\mathrm{HDL}, \text { rel. }}=1.0882 \times D_{\mathrm{Rd}, \text { rel. }}-0.85
$$

$v_{\mathrm{HDL}, \text { rel. }}$ relative decay rate $[-] ; D_{\mathrm{Rd}, \text { rel. }}$ relative resistance dose $[-]$.

Figure 3 shows the correlation between the $D_{\mathrm{Rd}}$, rel. and the resulting $v_{\mathrm{HDL}}$, rel. which is expected during outdoor exposure above ground (use class (UC) 3 conditions, EN 335, 2013). By the modifications, $D_{\mathrm{Rd}}$, rel. increased from 1.2 (untreated reference) to 14.6 (DMeDHEU $\left.+1 \% \mathrm{Mg}\left(\mathrm{NO}_{3}\right)_{2}\right)$ up to 87.1 $\left(\mathrm{DMDHEU}+5 \% \mathrm{Cu}\left(\mathrm{NO}_{3}\right)_{2}\right)$. Therefore, the $D_{\mathrm{Rd}}$ of resin-treated Scots pine sapwood is at least eleven times higher compared to an untreated reference of the same species. Transferred to a wooden construction such as a façade cladding or terrace decking, one can expect eleven times higher service life, if it is made from resintreated Scots pine sapwood compared to the same untreated wood at given exposure conditions (Meyer-Veltrup et al. 2017). Finally, wetting ability $\left(k_{\mathrm{wa}}\right)$ and resistance indicating factors $\left(k_{\text {inh }}\right)$ from laboratory tests enabled the prediction of high biological durability for DMDHEU, mDMDHEU and DMeDHEU treated wood outdoors, which were in the range of tropical hardwoods (i.e., bongossi, teak, merbau) with a high natural durability (Fig. 3). The latter had been tested and confirmed 
Table 6 Factors accounting for the wetting ability $\left(k_{\text {wa }}\right)$ and for the inherent protective material properties $\left(k_{\text {inh }}\right)$ calculated with untreated Norway spruce (Picea abies (L.) H. Karst) as reference and the resulting resistance dose $D_{\mathrm{Rd}}$ according to Meyer-Veltrup et al. (2017)

\begin{tabular}{|c|c|c|c|c|c|c|c|}
\hline Cataly & & $k_{\mathrm{wa}}$ & & & $k_{\text {inh }}$ & & $D_{\mathrm{Rd}}$ \\
\hline Type & Conc. (\%) & $W 24_{\mathrm{EMC} \sim 100 \% \mathrm{RH}}$ & $W 24_{\mathrm{MC} \sim 0 \% \mathrm{RH}}$ & $C W U$ & T.v. & C.p. & \\
\hline
\end{tabular}

\section{Before leaching EN 84 (2020)}

Untreated reference

\begin{tabular}{|c|c|c|c|c|c|c|c|c|}
\hline- & - & 0.99 & 1.15 & 1.20 & 0.97 & 1.16 & 1.13 & 401 \\
\hline \multicolumn{9}{|l|}{ DMDHEU } \\
\hline \multirow[t]{3}{*}{$\mathrm{Mg}\left(\mathrm{NO}_{3}\right)_{2}$} & 1.0 & 1.55 & 1.71 & 1.10 & 1.10 & 5.23 & 6.77 & 2661 \\
\hline & 2.0 & 1.64 & 1.82 & 1.98 & 1.41 & 5.53 & 7.01 & 3488 \\
\hline & 5.0 & 1.62 & 1.78 & 1.29 & 0.99 & 3.54 & 5.83 & 2159 \\
\hline \multirow[t]{3}{*}{$\mathrm{MgCl}_{2}$} & 1.0 & 1.56 & 1.50 & 0.71 & 1.26 & 6.65 & 7.52 & 3114 \\
\hline & 2.0 & 1.61 & 1.93 & 1.11 & 1.06 & 6.56 & 7.23 & 3203 \\
\hline & 5.0 & 1.55 & 1.43 & 1.76 & 0.69 & 3.85 & 4.88 & 1926 \\
\hline \multirow[t]{3}{*}{$\mathrm{Cu}\left(\mathrm{NO}_{3}\right)_{2}$} & 1.0 & 1.44 & 2.00 & 0.84 & 2.87 & 4.57 & 8.09 & 3677 \\
\hline & 2.0 & 1.45 & 2.08 & 0.79 & 3.40 & 7.63 & 9.26 & 5289 \\
\hline & 5.0 & 1.40 & 1.98 & 0.71 & 4.31 & 7.90 & 18.00 & 8839 \\
\hline \multicolumn{9}{|c|}{ mDMDHEU } \\
\hline $\mathrm{Mg}\left(\mathrm{NO}_{3}\right)_{2}$ & 1.0 & 1.28 & 1.59 & 1.06 & 0.90 & 8.73 & 9.19 & 3518 \\
\hline $\mathrm{MgCl}_{2}$ & & 1.35 & 1.48 & 1.06 & 0.79 & 6.30 & 7.34 & 2595 \\
\hline $\mathrm{Cu}\left(\mathrm{NO}_{3}\right)_{2}$ & & 1.35 & 1.81 & 1.38 & 1.24 & 3.59 & 6.02 & 2260 \\
\hline \multicolumn{9}{|c|}{ DMeDHEU } \\
\hline $\mathrm{Mg}\left(\mathrm{NO}_{3}\right)_{2}$ & 1.0 & 1.35 & 1.27 & 1.13 & 0.48 & 1.95 & 3.36 & 911 \\
\hline $\mathrm{MgCl}_{2}$ & & 1.38 & 1.68 & 1.65 & 0.49 & 2.73 & 4.78 & 1589 \\
\hline $\mathrm{Cu}\left(\mathrm{NO}_{3}\right)_{2}$ & & 1.41 & 1.63 & 1.78 & 0.64 & 2.11 & 3.74 & 1295 \\
\hline \multicolumn{9}{|c|}{ After leaching EN 84 (2020) } \\
\hline \multicolumn{9}{|c|}{ Untreated reference } \\
\hline- & - & 0.99 & 1.15 & 1.20 & 0.97 & 1.13 & 1.16 & 401 \\
\hline \multicolumn{9}{|l|}{$D M D H E U$} \\
\hline \multirow[t]{3}{*}{$\mathrm{Mg}\left(\mathrm{NO}_{3}\right)_{2}$} & 1.0 & 1.66 & 1.38 & 0.95 & 1.43 & 18.00 & 12.06 & 6616 \\
\hline & 2.0 & 1.68 & 1.76 & 0.93 & 1.47 & 15.20 & 18.00 & 7890 \\
\hline & 5.0 & 1.73 & 1.81 & 0.84 & 1.45 & 13.07 & 18.00 & 7348 \\
\hline \multirow[t]{3}{*}{$\mathrm{MgCl}_{2}$} & 1.0 & 1.87 & 1.93 & 0.66 & 1.21 & 18.00 & 18.00 & 8303 \\
\hline & 2.0 & 1.89 & 1.90 & 0.81 & 1.59 & 17.04 & 18.00 & 8820 \\
\hline & 5.0 & 1.75 & 1.78 & 0.95 & 1.25 & 18.00 & 18.00 & 8388 \\
\hline \multirow[t]{3}{*}{$\mathrm{Cu}\left(\mathrm{NO}_{3}\right)_{2}$} & 1.0 & 1.68 & 1.75 & 0.78 & 15.04 & 6.35 & 17.41 & 18,109 \\
\hline & 2.0 & 1.77 & 1.77 & 0.76 & 6.19 & 8.07 & 18.00 & 10,895 \\
\hline & 5.0 & 1.77 & 1.82 & 0.88 & 18.00 & 13.03 & 18.00 & 28,318 \\
\hline \multicolumn{9}{|c|}{ mDMDHEU } \\
\hline $\mathrm{Mg}\left(\mathrm{NO}_{3}\right)_{2}$ & 1.0 & 1.49 & 1.68 & 0.94 & 1.24 & 18.00 & 18.00 & 7844 \\
\hline $\mathrm{MgCl}_{2}$ & & 1.55 & 1.62 & 0.77 & 1.29 & 18.00 & 18.00 & 7653 \\
\hline $\mathrm{Cu}\left(\mathrm{NO}_{3}\right)_{2}$ & & 1.50 & 1.48 & 1.11 & 2.55 & 5.68 & 14.12 & 5350 \\
\hline \multicolumn{9}{|c|}{ DMeDHEU } \\
\hline $\mathrm{Mg}\left(\mathrm{NO}_{3}\right)_{2}$ & 1.0 & 1.12 & 1.31 & 1.16 & 0.73 & 9.03 & 18.00 & 4761 \\
\hline $\mathrm{MgCl}_{2}$ & & 1.14 & 1.19 & 1.03 & 0.80 & 12.04 & 18.00 & 5078 \\
\hline $\mathrm{Cu}\left(\mathrm{NO}_{3}\right)_{2}$ & & 1.13 & 1.39 & 1.18 & 2.20 & 8.53 & 18.00 & 6355 \\
\hline
\end{tabular}




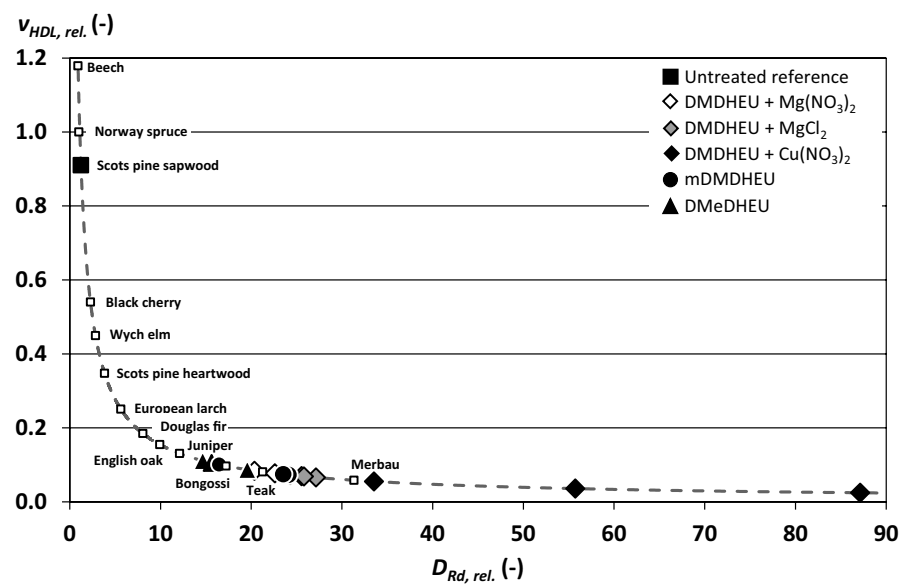

Fig. 3 Relationship between calculated relative $D_{\mathrm{Rd}}$ and predicted relative decay rate $\left(v_{\text {rel., HDL }}\right)$ for the modified and leached materials tested based on the model proposed by Meyer-Veltrup et al. (2017) and optimized by Brischke et al. (2021). Reference species was Norway spruce and $D_{\mathrm{Rd}}$ values for further untreated wood species (squares) were taken from Meyer-Veltrup et al. (2017) and Alfredsen et al. (2021)

under real-life conditions for treatments with the N-methylol compound DMDHEU (Emmerich et al. 2020a), but not yet for treatments with ultra-low formaldehyde containing mDMDHEU or even formaldehyde-free DMeDHEU.

\section{Conclusion}

Treatments of wood with cyclic N-methylol (DMDHEU, mDMDHEU) and $\mathrm{N}$-methyl (DMeDHEU) compounds decreased the water uptake and release and increased the resistance against decay by white (here: $T$. versicolor) and brown rot fungi (here: $C$. puteana) remarkably. However, high fluctuations were observed in water uptake and release as well as $M L$ caused by fungal decay, when modified specimens were tested without passing through a cold-water leaching. Consequently, a significant effect of the leaching procedure according to EN 84 (2020) on the durability classification could be established, which showed opposite effects compared to biocidal treatments (wood preservatives), normally showing lower durability after cold-water leaching. The effects of leaching were even more pronounced for treatments with low-fixating $\mathrm{N}$-methyl compounds in comparison with high-fixating $\mathrm{N}$-methylol compounds. Thus, in contrast to untreated wood testing, the leaching procedure appeared essential for a reliable durability classification of resin-treated wood, which partly contains non-fixated chemicals. Based on test data with modified and leached specimens, both $\mathrm{N}$-methylol and $\mathrm{N}$-methyl compounds increased 
the durability of Scots pine sapwood from 'not durable' (DC 5) to 'very durable to durable' (DC 1-2). It was hypothesized that the deposition of the resin molecules, and most probably the co-condensation with the cell wall polymers, was the dominant factor in reducing the availability for water within the cell wall, thereby affecting decay by fungi. Finally, wetting ability $\left(k_{\text {wa }}\right)$ and resistance indicating factors $\left(k_{\text {inh }}\right)$ allowed the prediction of high biological durability for the tested materials outdoors above ground. However, further field test studies are required to prove the performance of mDMDHEU and DMeDHEU modified specimens under real-life conditions.

Acknowledgements The authors acknowledge and cordially thank Max Schilling for assistance with the water uptake tests. The Archroma Management $\mathrm{GmbH}$ is acknowledged for providing the modification chemicals.

Funding Open Access funding enabled and organized by Projekt DEAL.

\section{Declarations}

Conflict of interest The authors declare that they have no conflict of interest.

Open Access This article is licensed under a Creative Commons Attribution 4.0 International License, which permits use, sharing, adaptation, distribution and reproduction in any medium or format, as long as you give appropriate credit to the original author(s) and the source, provide a link to the Creative Commons licence, and indicate if changes were made. The images or other third party material in this article are included in the article's Creative Commons licence, unless indicated otherwise in a credit line to the material. If material is not included in the article's Creative Commons licence and your intended use is not permitted by statutory regulation or exceeds the permitted use, you will need to obtain permission directly from the copyright holder. To view a copy of this licence, visit http://creativecommons.org/licen ses/by/4.0\%.

\section{References}

Alfredsen G, Brischke C, Marais BN, Stein RF, Zimmer K, Humar M (2021) Modelling the material resistance of wood-Part 1: utilizing durability test data based on different reference wood species. Forests 12:558

Alfredsen G, Flæte PO, Militz H (2013) Decay resistance of acetic anhydride modified wood: a review. Int Wood Prod J 4:137-143

Alfredsen G, Ringman R, Pilgård A, Fossdal CG (2015) New insight regarding mode of action of brown rot decay of modified wood based on DNA and gene expression studies: a review. Int Wood Prod J $6: 5-7$

Andrews BA, Trask-Morrell BJ (1997) Long term formaldehyde emissions from DMDHEU-finished cotton fabrics. Text Chem Color 29:16-19

Bajaj P (2002) Finishing of textile materials. J Appl Polym Sci 83:631-659

Bollmus S (2011) Biologische und technologische Eigenschaften von Buchenholz nach einer Modifizierung mit 1,3-dimethylol-4,5-dihydroxyethyleneurea (DMDHEU) [Biological and technological properties of beech after modification with 1,3-dimethylol-4,5-dihydroxyethyleneurea (DMDHEU)]. Ph.D. thesis. Goettingen, Germany, University of Goettingen

Bollmus S, Bächle L, Brischke C, Militz H (2019) Durability classification of preservative treated and modified wood. The International Research Group on Wood Protection, Stockholm, IRG/ WP/19-20659 
Brelid PL, Westin M (2007) Acetylated wood-results from long-term field tests. In: Proceedings of the 3rd European conference on wood modification, Bangor, United Kingdom, pp 71-78

Brischke C, Alfredsen G, Humar M, Conti E, Cookson L, Emmerich L, Flæte PO, Fortino S, Francis L, Hundhausen U, Irbe I, Jacobs K, Klamer M, Kržišnik D, Lesar B, Melcher E, Meyer-Veltrup L, Morrell JJ, Norton J, Palanti S, Presley G, Reinprecht L, Singh T, Stirling R, Venäläinen M, Westin M, Wong AHH, Suttie E (2021) Modeling the material resistance of wood-Part 2: validation and optimization of the Meyer-Veltrup model. Forests 12:576

CEN/TS 15083-2 (2005) Durability of wood and wood-based products - Determination of the natural durability of solid wood against wood-destroying fungi, test methods - Part 2: Soft rotting microfungi. CEN (European committee for standardization), Brussels, Belgium

Dhiman G, Chakraborty JN (2017) Assessment of durable press performance of cotton finished with modified DMDHEU and citric acid. Fash Text 4:1-18

Emmerich L, Militz H (2020) Study on the impregnation quality of rubberwood (Hevea brasiliensis Müll. Arg.) and English oak (Quercus robur L.) sawn veneers after treatment with 1,3-dimethylol-4,5-dihydroxyethyleneurea (DMDHEU). Holzforschung 74:362-371

Emmerich L, Bollmus S, Militz H (2019) Wood modification with DMDHEU (1.3-dimethylol-4.5-dihydroxyethyleneurea) - state of the art, recent research activities and future perspectives. Wood Mater Sci Eng 14:3-18

Emmerich L, Militz H, Brischke C (2020a) Long-term performance of DMDHEU-treated wood installed in different test set-ups in ground, above ground and in the marine environment. Int Wood Prod J 11:27-37

Emmerich L, Altgen M, Rautkari L, Militz H (2020b) Sorption behavior and hydroxyl accessibility of wood treated with different cyclic N-methylol compounds. J Mater Sci 55:16561-16575

Emmerich L, Brischke C, Sievert M, Schulz MS, Jaeger AC, Beulshausen A, Humar M (2020c) Predicting the Outdoor Moisture Performance of Wood Based on Laboratory Indicators. Forests 11:1001

Emmerich L, Bleckmann M, Strohbusch S, Brischke C, Bollmus S, Militz H (2021) Growth behaviour of wood-destroying fungi in chemically modified wood: wood degradation and translocation of nitrogen compounds. Holzforschung Ahead-of-Print. https://doi.org/10.1515/hf-2020-0252

EN 84 (2020) Wood preservatives - Accelerated ageing of treated wood prior to biological testing Leaching procedure. CEN (European committee for standardization), Brussels, Belgium

EN 113-2 (2021) Durability of wood and wood-based products - Test method against wood destroying basidiomycetes - Part 2: Assessment of inherent or enhanced durability. CEN (European committee for standardization), Brussels, Belgium

EN 252 (2015) Wood preservatives. Field test methods for determining the relative protective effectiveness in ground contact. CEN (European committee for standardization), Brussels, Belgium

EN 335 (2013) Durability of wood and wood-based products - Use classes: definitions, application to solid wood and wood-based products. CEN (European committee for standardization), Brussels, Belgium

EN 350 (2016) Durability of wood and wood-based products - Testing and classification of the resistance to biological agents, the permeability to water and the performance of wood and wood- based materials. CEN (European committee for standardization), Brussels, Belgium

EN 1609 (2013) Thermal insulating products for building applications - Determination of short term water absorption by partial immersion. CEN (European committee for standardization), Brussels, Belgium

Frick JG Jr (1985) Bonding in cotton fiber from formaldehyde-free crosslinks. J Appl Polym Sci 30:3467-3477

Frick JG Jr (1986) Effects of crosslink distribution in cotton fibers. Text Res J 56:124-130

Gérardin P (2016) New alternatives for wood preservation based on thermal and chemical modification of wood-a review. Ann for Sci 73:559-570

Holme I (1993) New developments in the chemical finishing of textiles. J Text Inst 84:520-533

Hill CAS (2009) Why does acetylation protect wood from microbiological attack? Wood Mater Sci Eng $4: 37-45$

Hill CAS (2011) Wood modification: an update. BioResources 6:918-919

Isaksson T, Brischke C, Thelandersson S (2013) Development of decay performance models for outdoor timber structures. Mater Struct 46:1209-1225

Isaksson T, Thelandersson S, Jermer J, Brischke C (2014) Beständighet för utomhusträ ovan mark. Guide för utformning och materialval [Durability of wood exposed outdoors above ground. Guideline 
for design and material selection]. Report TVBK-3066, Division of Structural Engineering, Lund University

Jones D, Sandberg D (2020) A Review of Wood Modification Globally-Updated Findings from COST FP1407. Interdisciplinary Perspectives on the Built Environment 1:1-31

Jung HZ, Benerito RR, Gonzales EJ, Berni RJ (1969) Influence of structure of cyclic urea derivatives on their reactivities with cotton. J Appl Polym Sci 13:1949-1963

Krause A (2006) Holzmodifizierung mit N-Methylolvernetzern [Wood modification with N-methylol crosslinking agents]. Ph.D. thesis. Goettingen, Germany, University of Goettingen.

Krause A, Jones D, Van der Zee M, Militz H (2003) Interlace treatment-wood modification with $\mathrm{N}$-methylol compounds. In: Proceedings of the first European conference on wood modification, Ghent, Belgium, 317-327

Meyer L, Brischke C, Preston A (2016) Testing the durability of timber above ground: a review on methodology. Wood Mater Sci Eng 11:283-304

Meyer-Veltrup L, Brischke C, Alfredsen G, Humar M, Flæte PO, Isaksson T, Brelid PL, Westin M, Jermer J (2017) The combined effect of wetting ability and durability on outdoor performance of wood: development and verification of a new prediction approach. Wood Sci Technol 51:615-637

Meyer L, Brischke C, Pilgård A (2012) Modified timber in various above ground exposures-durability and moisture performance. In: Proceedings of the 6th European conference on wood modification, Ljubljana, Slovenia, 137-144

Militz H (1993) Treatment of timber with water soluble dimethylol resins to improve their dimensional stability and durability. Wood Sci Technol 27:347-355

Naderpour F, Mirjalili SA, Sharzehee M (2009) The Investigation on the influence of DMDHEU on the Wrinkle and Abrasion Resistance of Cotton Fabrics using Image Processing. Text Res J 79:1571-1577

Paul R (Ed.) (2014) Functional finishes for textiles: improving comfort, performance and protection. Woodhead Publishing Series in Textiles. Elsevier. https://doi.org/10.1016/C2013-0-16373-8

Ringman R, Pilgård A, Brischke C, Richter K (2014) Mode of action of brown rot decay resistance in modified wood: a review. Holzforschung 68:239-246

Ritschkoff AC, Rättö M, Nurmi A, Kokko H, Rapp A, Militz H (1999) Effect of some resin treatments on fungal degradation reactions. The International Research Group on Wood Protection, Stockholm, IRG/WP/99-10318

Rowell RM (2014) Acetylation of wood - A review. Int J Lignocellul Prod 1:1-27

Rowell RM (2012) Chemical modification of wood to produce stable and durable composites. Cell Chem Technol 46:443-448

Rowell RM, Dickerson JP (2014) Acetylation of wood. In: Deterioration and protection of sustainable biomaterials. American Chemical Society, pp 301-327

Rowell RM, Ibach RE, McSweeny J, Nilsson T (2009) Understanding decay resistance, dimensional stability and strength changes in heat-treated and acetylated wood. Wood Mater Sci Eng 4:14-22

Sandberg D, Kutnar A, Mantanis G (2017) Wood modification technologies-a review. Iforest 10:895-908

Schaffert S (2006) Steuerung und Optimierung von Holzvernetzungsprozessen [Control and optimization of wood crosslinking processes]. Ph.D. thesis. Goettingen, Germany, University of Goettingen.

Schindler WD, Hauser PJ (2004) Chemical finishing of textiles. Woodhead Publishing Ltd, Cambridge

Stamm AJ, Seborg RM (1936) Minimizing wood shrinkage and swelling. J Ind Eng Chem 28:1164-1169

Thybring EE, Piqueras S, Tarmian A, Burgert I (2020) Water accessibility to hydroxyls confined in solid wood cell walls. Cellulose 27:5617-5627

Tomasino C (1992) Chemistry and technology of fabric preparation and finishing. North Carolina State University, Raleigh

Vanneste M (2014) Easy care finishes for textiles, Chapter 7. In: Paul R (ed) Functional Finishes for Textiles: Improving Comfort, Performance and Protection, Woodhead Publishing Series in Textiles Number 156. Elsevier, London, pp 227-256

Verma P, Junga U, Militz H, Mai C (2009) Protection mechanisms of DMDHEU treated wood against white and brown rot fungi. Holzforschung 63:371-378

Wepner F (2006) Entwicklung eines Modifizierungsverfahrens für Buchenfurniere (Fagus sylvatica L.) auf Basis von zyklischen N-Methylol-Verbindungen [Development of a wood modification process for beech veneers (Fagus sylvatica L.) on the basis of cyclic N-methylol compounds]. Ph.D. thesis. Goettingen, Germany, University of Goettingen.

Xie Y, Krause A, Mai C, Militz H, Richter K, Urban K, Evans PD (2005) Weathering of wood modified with the N-methylol compound 1,3-dimethylol-4,5-dihydroxyethyleneurea. Polym Degrad Stab 89:189-199 
Xie Y, Krause A, Militz H, Mai C (2008) Weathering of uncoated and coated wood treated with methylated 1,3-dimethylol-4,5-dihydroxyethyleneurea (mDMDHEU). Holz Roh Werkst 66:455-464

Ziifle HM, Benerito RR, Gonzales EJ, Berni RJ (1968) Kinetics of the reactions of ethyleneurea derivatives with cotton cellulose: Part III: The cellulose-dimethyldihydroxyethyleneurea reaction. Text Res J 38:925-930

Publisher's Note Springer Nature remains neutral with regard to jurisdictional claims in published maps and institutional affiliations. 